\title{
Resistance Mechanisms of Tomato (Solanum lycopersicum) to Root-Knot Nematodes (Meloidogyne species)
}

\author{
Mengistu Wubie and Zebyder Temesgen*
}

Department of Horticulture, College of Agriculture and Natural Resources, DebreMarkos University, P. O. Box 269, DebreMarkos, Ethiopia.

Received 2 October, 2018; Accepted 28 November, 2018

\begin{abstract}
Root-knot nematodes (Meloidogyne species) are the most devastating and as such they cause significant yield loss in tomato production. They are widely distributed in major tomato producing areas especially in warm climatic conditions. Because of the environmental impact of the application of pesticides, the use of nematode resistant varieties is becoming the most effective alternative to control root-knot nematodes. Several resistance genes are identified from wild tomato and other species. However, Mi-1 resistance gene is the only well characterized and used in many commercial tomato cultivars. A single dominant gene (Mi-1) with a hypersensitive response (HR), which is characterized by a local cell death at the site of nematode penetration and necrotic lesions of the surrounding tissue controls the resistance. Thus, Mi-1 gene either inhibits the penetration of second juvenile stage (J2), reduces number of gall formation, or reduces further development and reproduction rate of the nematode. However, the gene is a temperature dependent and broken by the virulent pathotypes. Plant growth hormones such as salicylic acid (SA) and jasmonic acid (JA) are involved in induced resistance, which is activated after infection. Secondary plant metabolites including amino acids, phenols, and lipophilic molecules were increased in resistant varieties as defense mechanism. The durability of the Mi-gene is a major concern since the resistance lost at high temperature. Heat stable resistance gene (Mi-9) is identified from Solannum arcanum. Hence, pyramiding of the resistance genes in commercial cultivars and genetic modification of plant metabolites might improve the durability of the gene.
\end{abstract}

Key words: Solanum lycopersicum, Meloidogyne species, Mi-gene, hypersensitive response (HR), induced resistance.

\section{INTRODUCTION}

Tomato (Solanum lycopersicum) belongs to Solonacea family and is one of the major vegetable crops in the world. Tomato is produced for the fresh market and processing. It is a major source of minerals, vitamins, and provides health benefits in human consumption (Robertson and Labate, 2007). Tomato ranks fourth among the leading vegetable crops in the world. According to FAO (2013), China, United States, Turkey,

*Corresponding author. E-mail: zebihorty@gmail.com.

Author(s) agree that this article remain permanently open access under the terms of the Creative Commons Attribution 
India, and Egypt are the top five leading tomato producing countries.

Despite its economic value, various pests and diseases influence the productivity of tomato. Plant-parasitic nematodes are soil living microscopic roundworms that affect root system of host plants. Among plant parasitic nematodes, root-knot nematodes (RKN) Meloidogyne species: Meloidogyne incognita, Meloidogyne javanica and Meloidogyne arenaria cause severe damage in vegetable crops including tomato (Sikora and Fernandez, 2005). They are widely distributed in many areas of tomato production field. In a field survey conducted on 25 tomato growing areas of Pakistan, $88 \%$ of the sites were infested with root-knot nematodes (Kamran et al., 2010). Of which $52.8 \%$ of the infestation was mainly $M$. incognita alone or in combination with $M$. javanica. Another survey conducted in 8 different localities tomato field in India showed that the crop is infected with root-knot nematodes in all 8 localities (Esfahani, 2012). In these areas, $M$. javanica and $M$. incognita were identified occurring either singly or in mixed population. They are potential risk in sandy soils and warm climatic conditions (Greco and Di Vito, 2011). RNK have wide host range and can survive in the soil as eggs or infective second juvenile stage for a long period of time in the absence of suitable host. During infection, the root-knot nematodes form typical symptom of gall, which varies from $1 \mathrm{~mm}$ up to $2 \mathrm{~cm}$ in diameter. Thus, the gall disrupts the normal functioning of xylem tissue of the host plant. The size of the gall depends on age of infection, number of nematodes inside the gall, species of nematodes and host plants (Greco and Di Vito, 2010). The level of crop losses highly depends on the initial population of the nematodes, susceptibility of the crop, age of the plant, cropping sequence, and involvement of other pathogens (Anamika et al., 2011). In susceptible tomato varieties, root-knot nematodes cause delay in flowering, reduction in fresh and dry weight of roots, stems, and leaves; and reduction in fresh fruit yield (Udo et al., 2008). Moreover, seed production per fruit is dramatically reduced. No seed per fruit might occur if the infection is very high (Corbett et al., 2011).

The use of resistant tomato varieties is the most effective, economically feasible, and environmentally method to manage RKN (Sorribas et al., 2005). Due to environmental impact of application of chemical, resistant cultivars are currently the best alternatives for controlling RKN. It is also recommended that resistant cultivars to be used as an integrated management of RKN. In a study conducted for four cropping seasons, crop rotation with resistant tomato reduced the nematode population by $90 \%$ and on average high yield has obtained when the resistant tomato cultivated for two consecutive years (Talavera et al., 2009). Resistance genes to RKN are identified from wild species of tomato and other plant species. However, in tomato, a single dominant (Mi-1) resistance gene is well known resistance gene to RKN and major insect pests such as white flies and aphids (Casteel et al., 2006). The Mi-1 gene is used in many breeding programs to develop high yielding hybrid and root-knot nematode resistant tomato varieties (Shrestha et al., 2012).

Several researches have been conducted to investigate how RNK react with tomato and the mechanism by which resistant tomato respond to RKN. Reviewing and discussing scientific papers is indispensable to identify research gaps and propose research areas. The objective of this review paper is, therefore, to briefly review and summarize research progresses on resistance mechanisms of tomato to root-knot nematodes. For this review, different research papers (not older than 2005) are searched from Google scholar and online literature database using the key words 'rootknot nematodes', 'tomato and root-knot nematodes', and 'root-knot nematodes and resistance gene'. In the first aspect of this review, the major resistance gene (Mi-1), its resistance mechanisms against RNK and inhibitory effect on nematode penetration are described. In the second aspect, induced resistance, the role of plant hormones in induced resistance to RKN, and the involvement of plant secondary metabolites in defense response of tomato to RKN are discussed. Lastly, the main points of the review and future remarks are pointed out

\section{TOMATO RESISTANCE TO ROOT-KNOT NEMATODES (RKN)}

\section{Major RKN resistance gene}

Though several genes are identified from wild tomato relative (Lycopersicon peruvianum) and other Solenaceaous species such as pepper, a single dominant gene (Mi-1) has been used for a long period as the only source of resistance to RKN in commercial tomato cultivars. Moreover, Mi- 1 is the best-characterized RKN resistance gene. The resistance is mediated by the presence of single dominant Mi-gene with a hypersensitive response (HR). The Mi-1 gene confers resistance to the three major Meloidogyne spp.: $M$. incognita, $M$. arenaria, and $M$. javanica (Branch et al., 2004). However, the effectiveness of the Mi-1 gene is temperature dependent. The gene loses its expression at soil temperature of $32^{\circ} \mathrm{C}$, which results in high infection by RKN (Zinovieva et al., 2013b). Heat stable resistance gene (Mi-9) which is a homolog of $\mathrm{Mi}-1$ has been identified from Solanum arcanum (Jablonska et al., 2007). Besides to temperature sensitivity, virulent populations of Meloidogyne spp. have also broken the Mi-1 gene. In a study conducted to compare the response of susceptible and resistant tomato cultivars to three populations of Tunisian $M$. incognita, the resistant cultivar carrying the Mi-1 gene did not show 

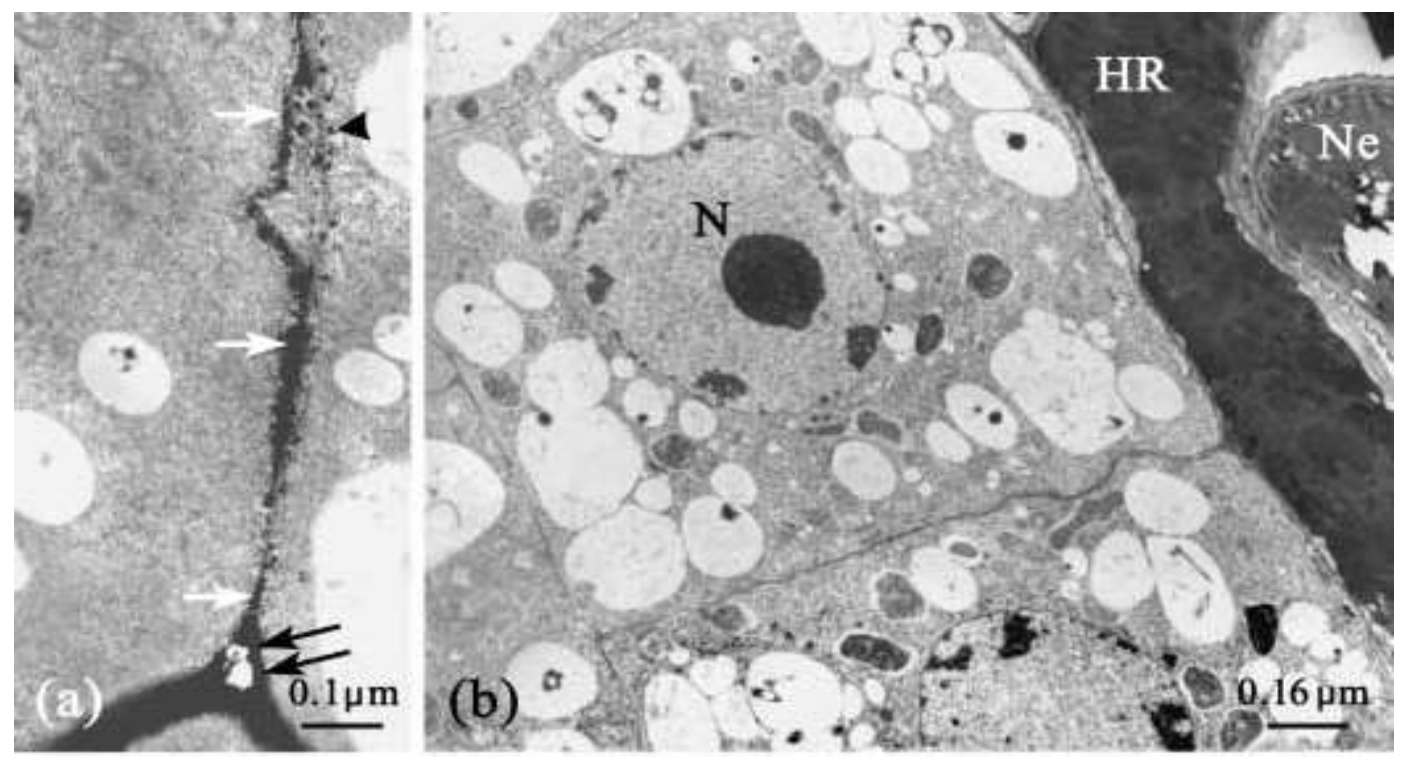

Figure 1. Subcellular localization of $\mathrm{H}_{2} \mathrm{O}_{2}$ production in resistant tomato roots infected with avirulent nematodes, as shown by electron microscopy. (a) Meristematic cells injured by the invading nematode (12 $h$ after inoculation) show high accumulation of $\mathrm{H}_{2} \mathrm{O}_{2}$ on their plasma membrane (arrowhead), cell walls (white arrow), and intercellular spaces (double arrows). (b) Hypersensitive reaction of cells selected as feeding site by the nematode is represented by dark, dying cells (HR) at $24 \mathrm{~h}$. Ne, Nematodes; N, nucleus; HR, hypersensitive reaction. Source: Melillo et al. (2006).

hypersensitive response (Regaieg and Horrigue-Raouani, 2012). Hence, J2 penetration and establishment feeding site with high giant cells was observed similar to the susceptible cultivar. The resistance is characterized by local cell death at the site of nematode penetration and necrotic lesions due to the accumulation of toxic substances (Melillo et al., 2006). The incompatible interaction between avirulent pathotype and resistant tomato varieties showed hypersensitive reaction at the site of nematode penetration (Figure 1b). Furthermore, significantly high level of reactive oxygen species (ROS) has been observed at a penetration site and adjacent cells when resistant tomato is infected with avirulent $M$. incognita pathotype (Figure 1a). High accumulation of hydrogen peroxide $\left(\mathrm{H}_{2} \mathrm{O}_{2}\right)$ observed on plasma membrane and cell wall with different concentration after inoculation. The effect of $\mathrm{H}_{2} \mathrm{O}_{2}$ on root-knot nematode has also been confirmed by applying different concentration of exogenous $\mathrm{H}_{2} \mathrm{O}_{2}$, which results in reduction in reproduction rate (eggs/g fresh root) of $M$. Javanica (Karajeh, 2008). Hence, the possible reasons for the reduction of nematode reproduction have suggested that $\mathrm{H}_{2} \mathrm{O}_{2}$ has direct killing effect on eggs or juveniles and indirect effect on endogenous $\mathrm{H}_{2} \mathrm{O}_{2}$ of treated plants.

\section{Mi-1 gene inhibits nematode penetration}

Second juvenile stage (J2) of the RKN enters the roots and induces formation of feeding site 'giant cells'. After formation of feeding sites, J2 become sedentary and develop to adult female. Then, the adult female lay eggs in external gelatinous matrix, which is visible as egg mass outside the roots. Infective J2 hatch from the eggs and start infecting other root parts of the same plant or migrate to the neighboring plant. However, in resistant tomato the processes are blocked either by inhibiting J2 penetrating, die after penetration or reducing the reproduction (Gharabadiyan et al., 2012). Hence, one of the resistance mechanisms of tomato to root-knot nematode is inhibiting the penetration of juvenile (J2) during invasion. However, there is variation in numbers of penetrating $\mathrm{J} 2$ depending on the nematode population, tomato genotype, and post-inoculation time (Melillo et al., 2006; Verdejo-Lucas et al., 2012). High number of eggs and egg masses per plant, eggs g-1 root, higher infection frequencies and multiplication rate has observed in a virulent population. In a study conducted to compare the resistance response to $M$. incognita of wild tomato species (L. peruvianum and Lycopersicon pimpinellifolium), local cultivars (CO3, PKM 1), and hybrid Ruchi significant difference was shown between susceptible and resistant wild tomato species with regard to the number of penetrated nematodes after inoculation (Hemaprabha and Balasaraswathi, 2008). In a resistant wild tomato ( $L$. peruvianum), the epidermis, endodermis, and vascular tissues of the root cells were intact after inoculation with infective juveniles. Lignin deposition has also been observed on epidermal layer of root section to 


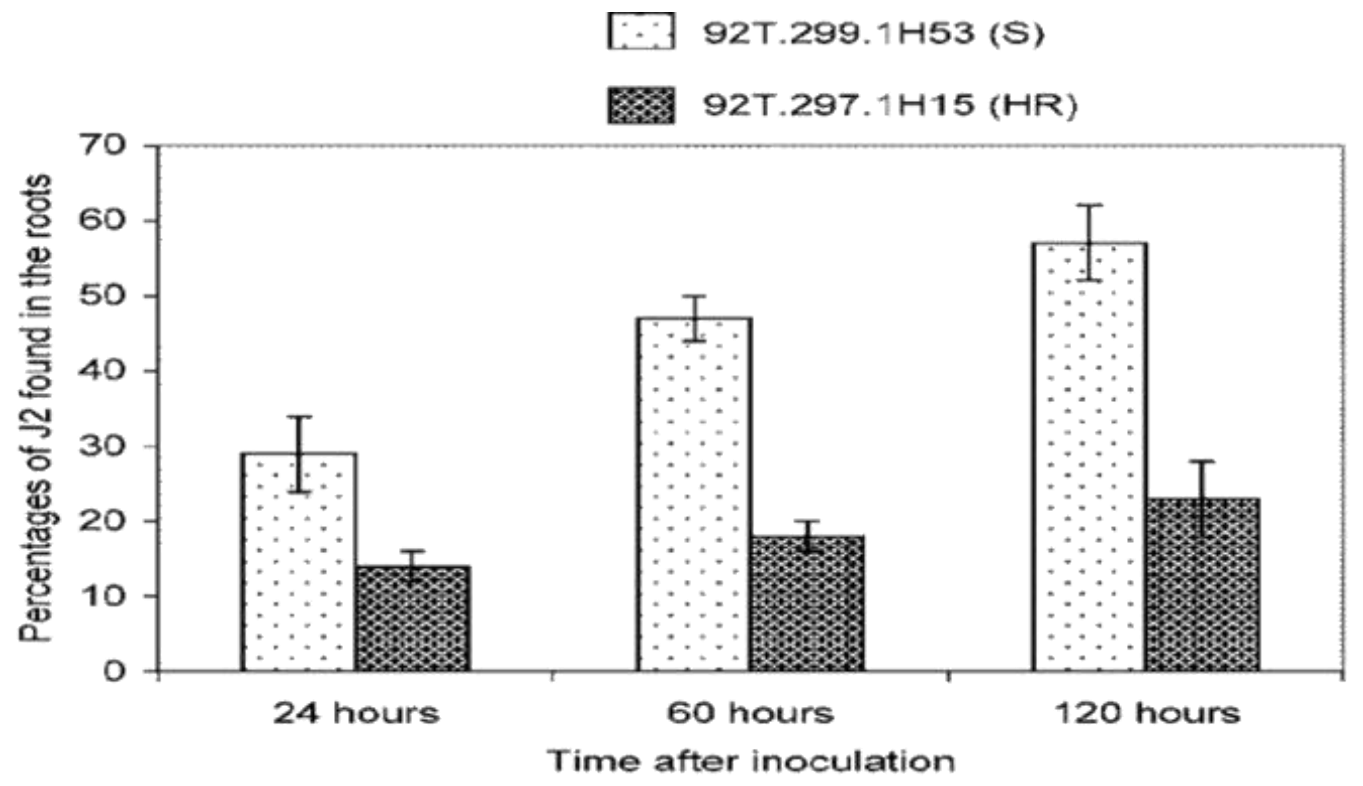

Figure 2. Dynamics of root invasion by second-stage juveniles (J2) of Meloidogync incognita in susceptible (S) and resistant (HR) genotypes. Source: Kouassi et al. (2005).

hinder the penetration of nematodes. The level of penetration depends on the period after inoculation. The rate of penetration after $24 \mathrm{~h}$ inoculation was double $(29 \%)$ in susceptible genotype as compared to the resistant one (14\%) (Kouassi et al., 2005). In susceptible genotypes, infectivity increases as the time after inoculation increases while there was no significant change in resistant genotype (Figure 2).

\section{Mi-mediated resistance reduces gall formation}

After penetration of the root, nematodes induce the formation of a gall in root tissue, which serves as criteria to assess susceptibility of tomato to root-knot nematodes. The resistance response of different genotypes of tomato were evaluated and screened with artificially inoculating J2 of $M$. incognita. The result showed that resistant wild tomato species showed very low number of gall (only 1 ) and 0.3 gall index (1-5 scale) while the susceptible cultivar showed a mean value of 89.66 galls and gall index of 4 (Hemaprabha and Balasaraswathi, 2008). Disease index (grade scale), calculated based on gall index was high on susceptible varieties and hybrids while very mild on resistant tomato, $L$. peruvianum. In addition, the reason for low number of galls and disease index in resistant tomato ( $L$. peruvianum) suggested that low number of nematodes had penetrated the root. However, as shown in Figure 3, the number of gall was significantly increased under high level of inoculum (Gharabadiyan et al., 2012). In another study conducted to evaluate the response of local and commercial tomato cultivars to $M$. javanica, root gall formation was significantly lower on commercial resistant cultivars (Rumbos et al., 2011). Similarly, significantly lower number of galls was observed on tomato cultivar grafted onto root-stock carrying Mi resistance gene as compared to the control or non-grafted.

\section{Reducing nematode reproduction}

The extent of growth reduction in tomato is directly proportional to the reproduction rate of the nematodes (Kamran et al., 2012). The Mi-1 mediated resistance significantly reduces the reproductive potential of rootknot nematodes (Corbett et al., 2011). The number of eggs $\mathrm{g}^{-1}$ root was very low on resistant cultivar and intermediate on grafted rootstock. Hence, the final population density of $M$. javanica was significantly reduced in resistant tomato having Mi-resistant gene as compared to the susceptible one (Verdejo-Lucas and Sorribas, 2008).

The reproduction of the nematodes was significantly affected by the genetic background of tomato (Cortada et al., 2009; Jacquet et al., 2005). The heterozygous and homozygous allelic condition of $\mathrm{Mi}$ gene in tomato influenced the reproduction potential of $M$. incognita. According to Jacquete et al. (2005), significant interaction has been observed between the plant genotypes (allelic variants of $M i$ gene) and nematode isolates on the reproduction of RKN. The result showed that the reproduction of a virulent $M$. incognita isolate was significantly higher in heterozygous (Mi/mi) allelic condition than homogenous $(\mathrm{Mi} / \mathrm{Mi})$ one. The reason for low reproduction potential of Salvia hisponica on 


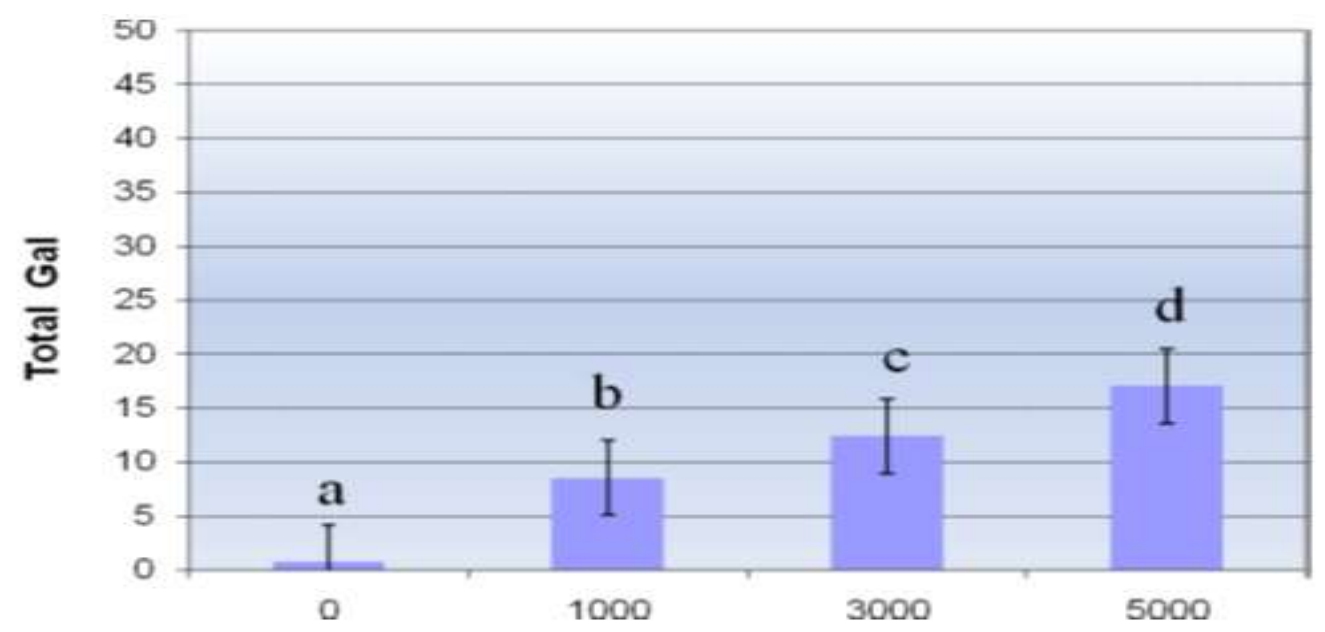

Nematode population level

Figure 3. Effect of inoculums levels on gall number. Source: Gharabadiyan et al. (2012).

homozygous $\mathrm{Mi} / \mathrm{Mi}$ tomato genotype was suggested that the $\mathrm{Mi}$ gene has dosage effect on nematode reproduction (Maleita et al., 2011). Contrasting reports exist on the effect of tomato genotype (Mi-1 homozygous or heterozygous locus) on reproduction of RKN. For instance, the heterozygous genotype showed significantly lower reproduction of $M$. javanica while higher nematode reproduction (eggs $\mathrm{g}^{-1}$ root) observed on homozygous resistant tomato cultivar (Cortada et al., 2009).

\section{Induced resistance}

Induced resistance is a plant defense response, which is activated by feeding damage by herbivorous and other biotic and abiotic factors. The defense mechanism is similar to that of major gene resistance, but unlike the major gene resistance, induced resistance confers partial resistance. For defense response to be activated, certain molecules are required for signal perception and transduction. It has been shown that plant hormones, jasmonic acid (JA) and salicylic acid (SA) have a role in signal transduction of tomato resistance to root-knot nematodes (Cooper et al., 2005; Zhang et al., 2011; Zinovieva et al., 2013b). The involvement of SA and JA in the process of induced resistance has been investigated by exogenous application of SA and JA on resistant and susceptible tomato cultivars infected with $M$. incognita (Zinovieva et al., 2013b). The result showed that SA and JA treatment reduced size of galls, number of galls, number of eggs, and female size on both the susceptible $(\mathrm{Mi}-)$ and resistance $(\mathrm{M}+)$ genotypes (Table 1). Moreover, enzyme activity of lypoxygenase (LOX), JA-biosynthesis enzyme, has increased when susceptible $(\mathrm{Mi}-)$ and resistant $(\mathrm{Mi+})$ tomato genotypes are treated with $\mathrm{JA}$
(Table 2). SA and JA treatment of resistant and susceptible at high temperature $\left(32^{\circ} \mathrm{C}\right)$ significantly reduced the infestation of $\mathrm{RKN}$, number of galls, and fertility of the females. Hence, unlike Mi-mediated resistance, JA and SA induced resistance is a stable resistance at high temperature. The number of root-knot nematodes was very low on JA over-expressed tomato mutants as compared to the control one.

In another study, the effect of JA on induced resistance to RKN was investigated by foliar application of JA to tomato cultivars with and without Mi-1.2 (Cooper et al., 2005). The result showed that JA induces systemic defense response, which results in reduction of nematode reproduction on susceptible tomato varieties. Moreover, application of JA did not show any inhibitory effect on Mi-mediated resistance. This shows that there is no signaling conflict between JA-induced resistance and Mi-mediated resistance. Comparison between JAinduced resistance and Mi-mediated resistance and their combined effect was also studied. Almost complete suppression of avirulent nematode reproduction has observed in Mi-1.2 mediated resistance while the JA treated susceptible cultivars showed only partial resistance. At high soil temperature $\left(32^{\circ} \mathrm{C}\right)$, the effect of Mi-1.2 significantly reduced while JA induced resistance was temperature independent.

It is also reported that SA has anti-inflammatory role to limit the spread of toxic peroxidative reactions from the nematode infected sites though its involvement on limiting nematode development and reproduction is not well known (Molinari and Loffredo, 2006). In another study, application of SA is found to be effective elicitor of resistance and reduce the reproduction and infestation of root-knot nematodes though the effectiveness depends on the concentration and methods of application 
Table 1. Effect of JA and SA on the resistance parameters of tomatoes to M. incognita at different temperatures

\begin{tabular}{|c|c|c|c|c|c|c|}
\hline $\begin{array}{l}\text { Temperature } \\
\left({ }^{\circ} \mathrm{C}\right)\end{array}$ & Genotype & Treatment & $\begin{array}{c}\text { Number of galls/1 } \mathrm{g} \\
\text { of roots) }\end{array}$ & $\begin{array}{l}\text { Size of galls } \\
\left(\mathrm{mm}^{2}\right)\end{array}$ & $\begin{array}{c}\text { Size of } \\
\text { female }\left(\mathrm{mm}^{2}\right)\end{array}$ & $\begin{array}{c}\text { Number of eggs in } \\
\text { ootheca }\end{array}$ \\
\hline \multirow{7}{*}{25} & & Control & 246 & 1.52 & 0.33 & 158 \\
\hline & $(\mathrm{Mi}-)$ & JA & 175 & 1.43 & 0.29 & 118 \\
\hline & & SA & 202 & 1.86 & 0.34 & 145 \\
\hline & & & & & & \\
\hline & & Control & 0 & No & No & No \\
\hline & $(\mathrm{Mi}+)$ & $\mathrm{JA}$ & 0 & - & - & - \\
\hline & & SA & 0 & - & - & - \\
\hline \multirow{8}{*}{32} & & Control & 264 & 1.84 & 0.31 & 162 \\
\hline & $(M i-)$ & JA & 205 & 1.68 & 0.32 & 121 \\
\hline & & SA & 218 & 1.93 & 0.34 & 164 \\
\hline & & & & & & \\
\hline & & Control & 147 & 1.32 & 0.33 & 63 \\
\hline & $(\mathrm{Mi}+)$ & $\mathrm{JA}$ & 73 & 1.28 & 0.31 & 36 \\
\hline & & SA & 62 & 1.16 & 0.24 & 23 \\
\hline & LSD* $^{*}$ & - & 40 & 0.35 & 0.03 & 15 \\
\hline
\end{tabular}

${ }^{*}$ Represents least significant difference (LSD) at $\mathrm{P}=0.95$.

Source: Zinovieva et al. (2013a).

Table 2. JA effect on LOX activity in leaves of tomatoes infested by the root-knot nematode at different temperatures.

\begin{tabular}{lcccc}
\hline \multirow{2}{*}{ Genotype treatment } & \multicolumn{4}{c}{ LOX activity in plant leaves, $\boldsymbol{E}_{\mathbf{2 3}} / \mathbf{( \mathbf { m g } / \mathbf { m i n } )}$} \\
\cline { 2 - 5 } & $\mathbf{2 5 ^ { \circ } \mathbf { C }}$ & $\mathbf{3 2}{ }^{\circ} \mathbf{C}$ & Healthy & Infested \\
\hline (Mi-) & Healthy & Infested & 0.22 & 0.3 \\
Control (water) & 0.2 & 0.34 & 0.26 & 0.44 \\
JA & 0.24 & 0.52 & Healthy & Infested \\
$(\mathrm{Mi+})$ & Healthy & Infested & 0.24 & 0.35 \\
Control (water) & 0.22 & 0.31 & 0.33 & 0.57 \\
JA & 0.28 & 0.3 & 0.06 & 0.06 \\
LSD $^{*}$ & 0.06 & 0.06 &
\end{tabular}

${ }^{*}$ Represents least significant difference (LSD) at $P=0.95$. Source: (Zinovieva et al., 2013a).

(Molinari and Baser, 2010).

Plant secondary metabolites influence the behaviour of root-knot nematodes (Campos et al., 2012; Dutta et al., 2012). A study was conducted to investigate the effect of small lipophilic molecules (SLM), root exudates of $S$. lycopersicum, on RKN. The root exudate was collected from tomato that grown in hydroponic culture in glasshouse chamber. SLMs were extracted through solid phase extraction and bioasssays were developed to test nematode stylet thrusting, motilty, imobility and mortality. The result showed that a significant decrease in stylet thrusting, nematode head movement and reduction in salivary secretion of Meloidogyne graminicola and $M$. incognita J2 (Dutta et al., 2012). It has also been observed that SLM inhibits the motility of J2. Moreover, high rate of mortality has been observed with undiluted solution of SLM. Thus, SLM causes nematostatic and nematotoxic effect when applied with diluted and undiluted solution, respectively. This property of SLM has been reported to be similar with volatile organic compounds (VOCs), root exudates of tomato and rice, which have a namatostatic effect, inhibitory effect on the mobility and secretion of salivary secretions of $\mathrm{J} 2$ of RKN (Ranganathan and Borges, 2009). It has been reported that many phytochemicals which are exudated from the root can act as repellents, attractants or inhibitors, and toxic effect on plant parasitic nematodes (Curtis et al., 2009).

A study was conducted to evaluate the metabolic responses of susceptible and tolerant tomato to $M$. incognita. The resistant and susceptible tomato cultivars were inoculated with $\mathrm{J} 2$ of $M$. incogniata. At time interval 
of $0,24,48$, and $96 \mathrm{~h}$ after inoculation, the roots were removed, washed, frozen and freeze-dried for subsequent quantification of aminoacids, phenols, alkalods, and soluble carbohydrates. The result showed that the concentration of amino acids and phenols has increased after inoculation with $M$. incognita in resistant tomato (Campos et al., 2012). The highest concentration of phenols was recorded at $96 \mathrm{~h}$ after inoculation. Thus, increasing of phenols concentration after inoculation in resistant tomato suggests that they are involved in preventing the formation of nematode feeding sites. Similarly, the concentration of carbohydrates in resistant tomato varied though its correlation with resistance to nematodes is not well understood.

\section{CONCLUSION AND FUTURE REMARKS}

Since application of chemical pesticides has a negative impact on environment, priority has been given to resistant tomato varieties to control root-knot nematode (RKN). The Mi-gene of tomato has provided effective control against the three major Meloidogyne spp. for many years. The resistance gene (Mi-gene) is characterized by hypersensitive response (HR) associated with local cell death at the site of penetration and necrotic lesions on nematode feeding sites. However, the gene loses its effectiveness at high temperature. Moreover, the Mi gene is broken by virulent RKN pathotypes. Nowadays, because of climate change the temperature is increasing from time to time in most parts of the world. Thus, the durability and effectiveness of the resistance gene to RKN is uncertain since Mi-gene is broken at high temperature. Heat-stable resistance genes to RKN have been identified in different tomato accessions. Furthermore, several resistance genes to RKN have been reported within Solanaceae family. Therefore, strategies need to be developed to improve the durability of the resistance. Pyramiding of these resistance genes in commercial tomato cultivars could be one possible approach to improve the durability of the resistance. Transgenic expression of some resistance genes has shown successful result. Plant secondary metabolites are reported to be involved directly or indirectly in signal transduction of $\mathrm{Mi}$ - mediated resistance genes. Thus, modification of the metabolic pathways (RKN damage induced expression) of these molecules by using modern biotechnology (genetic engineering) could be an alternative approach for developing resistant tomato varieties to RKN.

\section{CONFLICT OF INTERESTS}

The authors have not declared any conflict of interests.

\section{REFERENCES}

Anamika SS, Singh K, Ghosh G (2011). Distribution of root-knot nematode on major field crops in Uttar Pradesh (India). Archives of Phytopathology and Plant Protection 44:191-197.

Branch C, Hwang CF, Navarre DA, Williamson VM (2004). Salicylic acid is part of the Mi-1-mediated defense response to root-knot nematode in tomato. Molecular Plant-microbe Interactions 17:351-356.

Campos VAC, Machado ART, Oliveira DF, Campos VP, Chagas RCR, Nunes AS (2012). Changes in metabolites in plant roots after inoculation with Meloidogyne incognita. Nematology 14:579-588.

Casteel CL, Walling LL, Paine TD (2006). Behavior and biology of the tomato psyllid, Bactericerca cockerelli, in response to the Mi-1.2 gene. Entomologia Experimentalis et Applicata 121:67-72.

Cooper W, Jia L, Goggin L (2005). Effects of jasmonate-induced defenses on root-knot nematode infection of resistant and susceptible tomato cultivars. Journal of Chemical Ecology 31:1953-1967.

Corbett BP, Jia L, Sayler RJ, Arevalo-Soliz LM, Goggin F (2011). The Effects of Root-knot Nematode Infection and Mi-mediated Nematode Resistance in Tomato on Plant Fitness. Journal of Nematology 43:82.

Cortada L, Sorribas FJ, Ornat C, Andrés MF, Verdejo-Lucas S (2009). Response of tomato rootstocks carrying the Mi-resistance gene to populations of Meloidogyne arenaria, M. incognita and M. javanica. European Journal of Plant Pathology 124:337-343.

Dutta TK, Powers SJ, Gaur HS, Birkett M, Curtis RHC (2012). Effect of small lipophilic molecules in tomato and rice root exudates on the behaviour of Meloidogyne incognita and M. graminicola. Nematology 14:309-320.

Esfahani MN (2012). Distribution and identification of root-knot nematode species in tomato fields. Mycopath 7.

Food and Agriculture Organization (FAO) (2013). Production yearbook 2012. Food and agriculture organization. Rome, Italy.

Gharabadiyan F, Jamali S, Ahmadiyan Yazdi A, Eskandari A (2012). Source of resistance to root-knot nematode (Meloidogyne javanica) in tomato cultivars. Journal of Agricultural Technology 8:2011-2021.

Greco N, Di Vito M (2010). Main Nematode Problems of Tomato III International Symposium on Tomato Diseases 914:243-249.

Greco N, Di Vito M (2011). Main nematode problems of tomato. III International Symposium on Tomato Diseases 914:243-249.

Hemaprabha E, Balasaraswathi R (2008). Resistance to the root knot nematode Meloidogyne incognita in different tomato genotypes based on screening and cloning studies. Acta Phytopathologica et Entomologica Hungarica 43:187-199.

Jablonska B, Ammiraju JS, Bhattarai KK, Mantelin S, de llarduya OM, Roberts PA, Kaloshian I (2007). The Mi-9 gene from Solanum arcanum conferring heat-stable resistance to root-knot nematodes is a homolog of Mi-1. Plant physiology 143:1044-1054.

Jacquet $\mathrm{M}$, Bongiovanni $\mathrm{M}$, Martinez $\mathrm{M}$, Verschave $\mathrm{P}$, Wajnberg $\mathrm{E}$, Castagnone-Sereno P (2005). Variation in resistance to the root-knot nematode Meloidogyne incognita in tomato genotypes bearing the $\mathrm{Mi}$ gene. Plant Pathology 54:93-99.

Kamran M, Anwar S, Javed N, Khan S, Sahi G (2010). Incidence of root-knot nematodes on tomato in Sargodha, Punjab, Pakistan. Pakistan Journal of Nematology 28:253-262.

Kamran M, Anwar S, Javed N, Khan S, ul Haq I, Ullah I (2012). Field Evaluation of Tomato Genotypes for Resistance to Meloidogyne incognita. Pakistan Journal of Zoology 44:1355-1359.

Karajeh M (2008). Interaction of Root-Knot Nematode (Meloidogyne Javanica) and Tomato As Affected By Hydrogen Peroxide. Journal of Plant Protection Research 48(2):181-187.

Kouassi AB, Kerlan MC, Sobczak M, Dantec JP, Rouaux C, Ellisseche D, Mugniery D (2005). Genetics and phenotypic characterisation of the hypersensitive resistance of Solanum sparsipilum to Meloidogyne incognita. Nematology 7:213-225.

Maleita CM, Santos MCVD, Curtis RH, Powers SJ, de OAM Isabel (2011). Effect of the Mi gene on reproduction of Meloidogyne hispanica on tomato genotypes. Nematology 13:939-949.

Melillo MT, Leonetti $\mathrm{P}$, Bongiovanni M, Castagnone-Sereno $\mathrm{P}$, BleveZacheo T (2006). Modulation of reactive oxygen species activities and $\mathrm{H} 2 \mathrm{O} 2$ accumulation during compatible and incompatible tomatoroot-knot nematode interactions. New Phytologist 170:501-512.

Molinari S, Loffredo E (2006). The role of salicylic acid in defense response of tomato to root-knot nematodes. Physiological and Molecular Plant Pathology 68:69-78.

Molinari S, Baser N (2010). Induction of resistance to root-knot 
nematodes by SAR elicitors in tomato. Crop Protection 29:13541362.

Regaieg $\mathrm{H}$, Horrigue-Raouani N (2012). Histological response of resistant tomato cultivars to infection of virulent Tunisian root-knot nematode (Meloidogyne incognita) populations. Archives of Phytopathology and Plant Protection 45:2036-2045.

Robertson LD, Labate JA (2007). Genetic resources of tomato (Lycopersicon esculentum Mill.) and wild relatives. Genetic improvement of Solanaceous crops, Tomato 2:25-75.

Rumbos Cl, Khah EM, Sabir N (2011). Response of local and commercial tomato cultivars and rootstocks to Meloidogyne javanica infestation. Australian Journal of Crop Science 5:1388.

Shrestha S, Kumar R, Behera TK, Sharma HK (2012). Inheritance of resistance to root-knot nematode (Meloidogyne incognita race 1) in tomato (Solanum lycopersicum L.) 'Pusa 120'. Journal of Horticultural Science and Biotechnology 87:211-216.

Sikora RA, Fernandez E (2005). Nematode Parasites of Vegetables. Plant parasitic nematodes in subtropical and tropical agriculture, 319. Cabi.

Sorribas FJ, Ornat C, Verdejo-Lucas S, Galeano M, Valero J (2005). Effectiveness and profitability of the Mi-resistant tomatoes to control root-knot nematodes. European Journal of Plant Pathology 111:2938.

Talavera M, Verdejo-Lucas S, Ornat C, Torres J, Vela M, Macias F, Cortada L, Arias D, Valero J, Sorribas F (2009). Crop rotations with< i> $\mathrm{Mi}<\mathrm{i}>$ gene resistant and susceptible tomato cultivars for management of root-knot nematodes in plastic houses. Crop Protection 28:662-667.

Udo IA, Uguru MI, Ogbuji RO, Ukeh DA (2008). Sources of Tolerance to Root-Knot Nematode, Meloidogyne javanica, in Cultivated and Wild Tomato Species. Plant Pathology Journal 7(1):40-44.

Verdejo-Lucas S, Sorribas FJ (2008). Resistance response of the tomato rootstock SC 6301 to Meloidogyne javanica in a plastic house. European Journal of Plant Pathology 121:103-107.

Verdejo-Lucas S, Talavera M, Andrés M (2012). Virulence response to the $<$ i $>\mathrm{Mi} .1</ \mathrm{i}>$ gene of $<\mathrm{i}>$ Meloidogyne $</ \mathrm{i}>$ populations from tomato in greenhouses. Crop Protection 39:97-105.
Zhang L, Lei H, Yang R, Chen H, Cheng J, Wang S (2011). Effects of Jasmonatc on Proteinase Inhibitor II and Variation in Tomato Response to Root-Knot Nematodes. Acta Horticulturae 917:249-252.

Zinovieva S, Vasyukova N, Udalova ZV, Gerasimova N (2013a). The Participation of salicylic and jasmonic acids in genetic and induced resistance of tomato to Meloidogyne incognita (Kofoid and White, 1919). Biology Bulletin 40:297-303.

Zinovieva SV, Vasyukova NI, Udalova ZV, Gerasimova NG (2013b). The Participation of salicylic and jasmonic acids in genetic and induced resistance of tomato to Meloidogyne incognita (Kofoid and White, 1919). Biology Bulletin 40:297-303. 